\title{
Morphological Features of Pycnodysostosis with Emphasis on Clinical and Radiographic Maxillofacial Findings
}

\author{
Características Morfológicas de la Picnodisostosis con Énfasis \\ en Hallazgos Clínicos y Radiológicos Maxilofaciales
}

\author{
Alves, N."; Oliveira, R. J.**; Deana, N. F.*** \& Sampaio, J. C. A..****
}

\begin{abstract}
ALVES, N.; OLIVEIRA, R. J.; DEANA, N. F. \& SAMPAIO, J. C. A. Morphological features of pycnodysostosis with emphasis on clinical and radiographic maxillofacial findings. Int. J. Morphol., 31(3):921-924, 2013.

SUMMARY: Pycnodysostosis is a rare genetic syndrome characterized by short stature, obtuse mandibular angle, frontal, parietal and occipital bossing, open fontanels and cranial sutures, midfacial hypoplasia, acro-osteolysis of the distal phalanges, increased bone density, absence or hipopneumatization of the paranasal sinuses and normal laboratory studies. We report the case of a 35-year-old Brazilian man that was referred to a private clinic with history of dysmorphic facies for evaluation. The clinical and radiological features exhibited by the patient led to a diagnosis of pycnodysostosis. We describe the morphological features of pycnodysostosis with emphasis on the clinical and radiographic maxillofacial findings comparing the data obtained from our case with a literature review.
\end{abstract}

KEY WORDS: Pycnodysostosis; Morphology; Radiography.

\section{INTRODUCTION}

Pycnodysostosis is an autosomal recessive disorder, described in 1962 by Maroteaux \& Lamy, characterized by short stature, dysplasia of skull bones, obtuse mandibular angle, dysplasia of the clavicles and distal phalanges, increased bone density and normal laboratory studies (Elmore, 1966; Muto et al., 1991). The palate is narrow and grooved and there occurs delayed eruption of deciduous teeth. The permanent teeth are commonly irregular and teeth may be missing (hypodontia) (Chaudhary \& Chaudhary, 2012). Fonteles et al. (2007) still report the presence of maxillary retrusion, reduced facial height and open bite. Radiographically, generalized osteosclerosis, open fontanelles and cranial sutures, absence of facial sinuses can be observed.

The diagnosis is made with clinical features that are detectable at birth (Goodman \& Gorlin, 1977). The differential diagnosis of pycnodysostosis is established with osteopetrosis, cleidocranial dysplasia and idiopathic acroosteolysis (Alves Pereira et al., 2008). Patients with cleidocranial dysplasia show similar signs to thoseof pycnodysostosis, such as short height, agenesis or clavicular aplasia, frontal and parietal bossing, open fontanels and cranial sutures, however, bone density is not increased (Wolpowitz \& Matisonn, 1974; Alves \& Oliveira, 2008; Alves Pereira et al.). Patients with osteopetrosis have a difuse sclerosis and tendency for fracture as well as the patients with pycnodysostosis, however, extra-medullary hemopoiesis are present and the cranial nerves are involved with deafness, blindness and facial paralysis (Wolpowitz \& Matisonn; Bathi $\&$ Mansur, 2000). In the acro-osteolysis the appearance of the patients is typical, with exophthalmos and an upturned nose. Furthermore, the angle of the mandible is acute and increased bone density is not present (Landa et al., 2000).

The goal of this study was to describe the morphological features of pycnodysostosis with emphasis on the clinical and radiographic maxillofacial findings comparing the data obtained from our case with a literature review.

\footnotetext{
* CIMA, Facultad de Odontología, Universidad de La Frontera, Temuco, Chile.

** Facultad de Odontología, Universidade Metropolitana de Santos, Brazil.

**** Kinesiólogo, Temuco, Chile.

***** Cirujano-dentista, São Paulo, Brasil.
} 


\section{CASE REPORT}

A 35-year-old Bazilian man was referred to a private clinic located in São Paulo, Brazil with history of dysmorphic facies for evaluation. No history of consanguinity between parents, maternal and neonatal history was uneventful.

The patient reported several episodes of fractures: two of the right tibia, six of the left tibia, one of the left humerus and one of the nasal bones. On physical examination he had the following features: standing height $1.60 \mathrm{~m}$; hypermobile extremities; brachydactyly of hands and feet with dysplastic nails (Fig. 1A-B); absence of closing of the fontanels; frontal and occipital bossing (Fig. 2A); midfacial hypoplasia with proptosed eyes (Fig. 2B); anterior open bite (Fig. 3A); narrow high arched grooved palate (Fig. 3B). After clinical examination, the patient underwent radiographic examination with anteroposterior and lateral skull radiographs and anteroposterior radiographs of both hands. Films of the hands showed aplastic distal phalanges in keeping with acroosteolysis (Fig. 4). Skull films (Fig. 5A-B) showed wide sutures, hypoplastic maxilla, hipopneumatization of the frontal sinuses and the mandible was underdeveloped with an obtuse mandibular angle, being nearly straight.

The clinical and radiological features exhibited by the patient led to a diagnosis of pycnodysostosis.

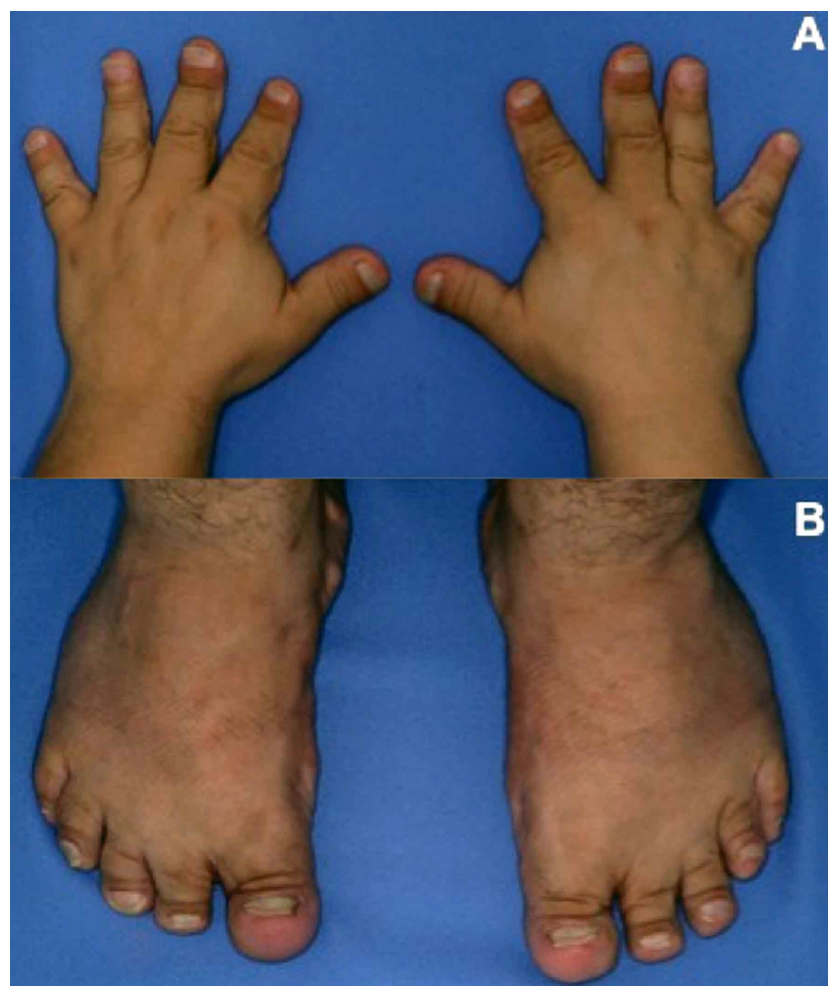

Fig. 1. Brachydactyly of hands (A) and feet (B) with displastic nails.

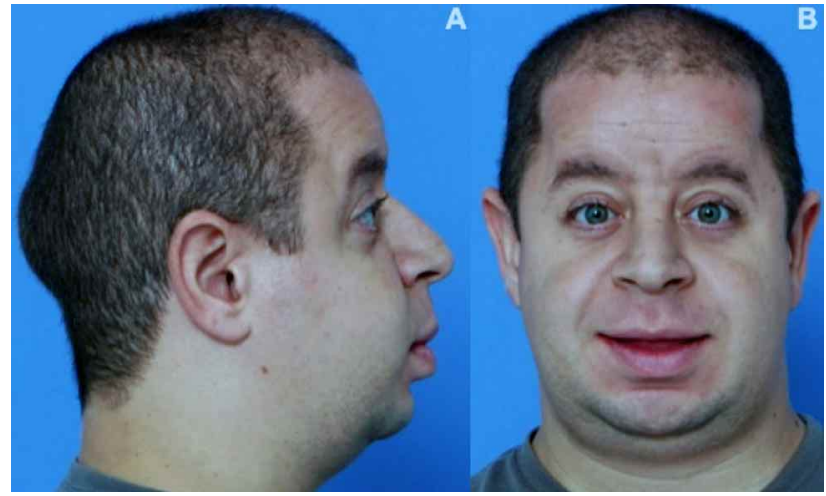

Fig. 2. Lateral (A) and anterior (B) aspects showing frontal and occiptal bossing; hooked nose; midfacial hypoplasia; retrognathia; proptosed eyes and convex facial profile.

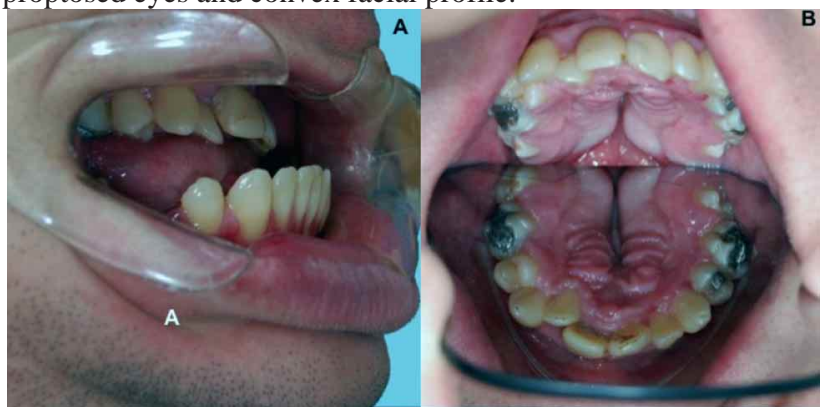

Fig. 3. Anterior open bite (A); narrow high arched grooved palate

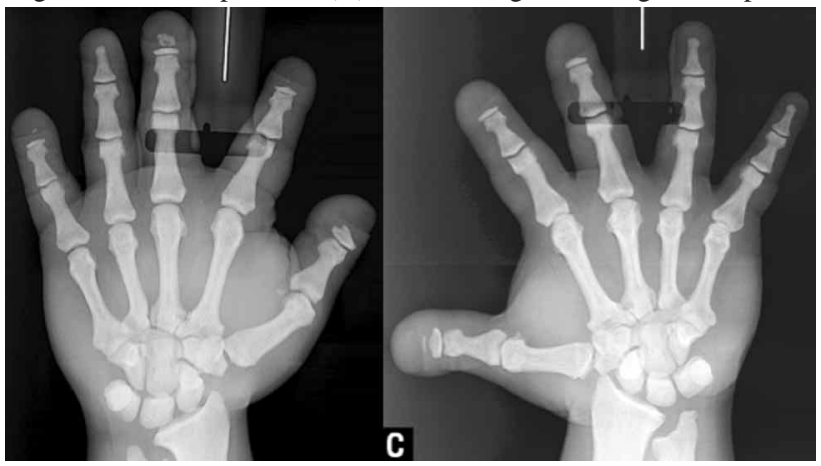

Fig. 4. Hand and wrist radiographs showing the acro-osteolysis of the distal phalanges.

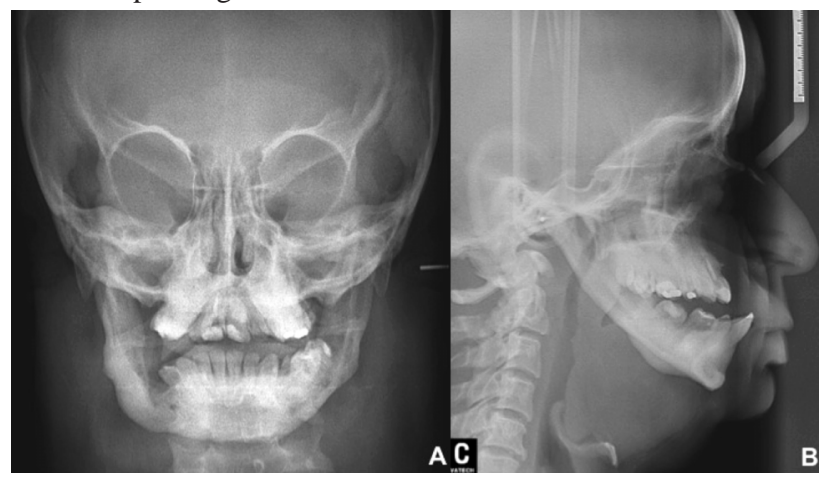

Fig. 5. Anterior (A) and lateral skull (B) radiographs showing maxillary hypoplasia, hypopneumatization of the frontal sinus; narrow mandible, obtuse mandibular angle; hypoplasia of the mandibular branch and anterior open bite. 


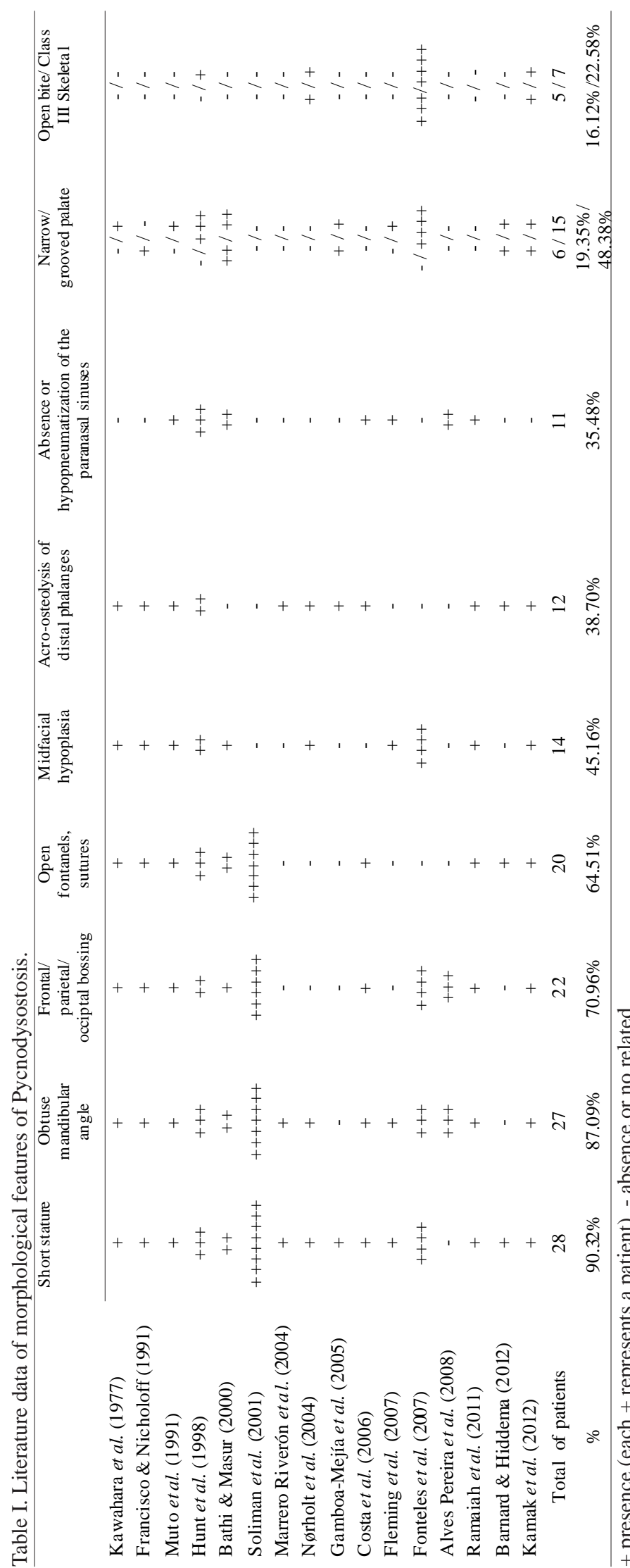

\section{DISCUSSION}

Table I shows the main morphological features of patients with pycnodysostosis, a rare disease that associates a characteristic appearance with an increase of bone fragility. Although the short stature is a constant feature, since it was present in $90.32 \%$ of patients involved in the reviewed literature, in our case the patient shows normal stature, fact also reported by Alves Pereira et al. in three clinical cases. Through our review of the literature, we still found the following main features: obtuse mandibular angle $(87.09 \%)$; frontal, parietal and occipital bossing (70.96\%); open fontanels and cranial sutures $(64.51 \%)$; grooved palate $(48.38 \%)$; midfacial hypoplasia (45.16\%); acro-osteolysis of distal phalanges (38.70\%); absence or hypopneumatization of the paranasal sinuses (35.48\%); class III skeletal (22.58\%); narrow palate $(19.35 \%)$; open bite $(16.12 \%)$. Our patient had these same characteristics, except parietal bossing and regarding absence or hypopneumatization of the paranasal sinuses, only the frontal sinus was hypopneumatized.

Our patient has no history of consanguinity between parents, our literature review however, found that parental consanguinity was present in 12 patients (38\%) (Kawahara et al., 1977; Muto et al.; Soliman et al., 2001; Costa et al., 2006; Fonteles et al.).

We agree with Muto et al. when they affirm that one of the most common features found in the mandible is the loss of the gonial angle. Through our review of the literature, we found obtuse mandibular angle in $87.09 \%$ of the cases, it was the second most common feature found. We also agree with Nørholt et al. (2004) when they affirm that due to the maxillary hypoplasia, these patients often present a Class III dentition. It is important to remember, that severe maxillary hypoplasia can result in obstructive sleep apnea that is a disorder in which complete or partial obstruction of the airway during sleep causes loud snoring, oxyhemoglobin desaturations and frequent arousals.

Our patient reported several episodes of fractures: two of the right tibia, six of the left tibia, one of the left humerus and one of the nasal bones. This is a big problem since it can occur with minimal stress. Our literature review revealed that the $48.38 \%$ of the patients had a multiples fractures (Kawahara et al.; Francisco \& Nicholoff, 1991; Muto et al.; Hunt et al., 1998; Bathi \& Masur; Nørholt et al.; Fonteles et al.; Alves 2 Pereira et al.; Barnard \& Hiddema, 2012). Muto et al. affirms + that usually the fractures happen in the long bone and the mandibular fracture occurs occasionally.

Reviewing the literature, we still found other alterations, such us: multiple impacted teeth, cross bite, enamel hipoplasia, ${ }_{+}$clavicular dysplasia, dental abnormalities, mandibular 
hipoplasia, wormian bones and supernumerary teeth (Kawahara et al.; Francisco \& Nicholoff; Muto et al.; Hunt et al.; Bathi \& Masur; Soliman et al.; Marrero Riverón et al., 2004; Nørholt et al.; Gamboa-Mejía et al., 2005; Costa et al.; Fleming et al., 2007; Fonteles et al.; Alves Pereira et al.; Barnard \& Hiddema; Kamak et al., 2012). However, these features were absent in our case.

Although biochemical and genetic knowledge in the field of the Pycnodysostosis are progressing, the clinical and radiological features are still the bases diagnosis of this disease. It is important to make the diagnosis as early as possible in order to plan the treatment more suitable to provide a better life's quality to the patients.

ALVES, N.; OLIVEIRA, R. J.; DEANA, N. F. \& SAMPAIO, J. C. A. Características morfológicas de la picnodisostosis con énfasis en hallazgos clínicos y radiológicos maxilofaciales. Int. J. Morphol., 31(3):921-924, 2013.

RESUMEN: La picnodisostosis es un síndrome genético raro caracterizado por baja estatura, ángulo de la mandíbula obtuso, prominencias frontal, parietal y occipital, suturas craneales y fontanelas abiertas, hipoplasia del tercio medio de la cara, acroosteolisis de las falanges distales, aumento de la densidad ósea, ausencia o hiponeumatización de los senos paranasales y exámenes de laboratorio normales. Se presenta un caso de paciente brasileño, 35 años de edad, sexo masculino, remitido a clínica privada con historia de facies dismórfico para evaluación. Las características clínicas y radiológicas exhibidas por el paciente llevaron al diagnóstico de picnodisostosis. Se describe las características morfológicas de la picnodisostosis con énfasis en los hallazgos clínicos y radiológicos maxilofaciales, comparando los datos obtenidos en nuestro caso con los hallazgos reportados en la literatura revisada.

PALABRAS CLAVE: Picnodisostosis; Morfología; Radiografía.

\section{REFERENCES}

Alves, N. \& Oliveira, R. Cleidocranial Dysplasia - A case report. Int. J. Morphol., 26(4):1065-8, 2008

Alves Pereira, D.; Berini Aytés, L. \& Gay Escoda, C. Pycnodysostosis. A report of 3 clinical cases. Med. Oral Patol. Oral Cir. Bucal, 13(10):E633-5, 2008.

Barnard, B. W. \& Hiddema, W. Pycnodysostosis with the focus on clinical and radiographic findings. S. Afr. J. Rad., 16(2):74-6, 2012.

Bathi, R. J. \& Masur, V. N. Pyknodysostosis--a report of two cases with a brief review of the literature. Int. J. Oral Maxillofac. Surg., 29(6):439-42, 2000.

Chaudhary, M. \& Chaudhary, S. D. Essentials of pediatric oral pathology. New Delhi, Jaypee Brothers Medical Publishers, 2012. p.267.

Costa, A. F.; Lopes, S. O. C.; Almeida, S. M. \& Steiner, C. Pycnodysostosis: An Early Case Report With Emphasis On The Radiographic Findings. Internet J. Dent. Sci., 3(2), DOI:10.5580/2d5, 2006.

Elmore, S. M. Pycnodysostosis: A review. J. Bone Joint Surg. Am., 49:153-62, 1967

Fleming, K. W.; Barest, G. \& Sakai, O. Dental and facial bone abnormalities in pyknodysostosis: CT findings. AJNR Am. J. Neuroradiol., 28(1):132-4, 2007.
Fonteles, C. S.; Chaves, C. M. Jr; Da Silveira, A.; Soares, E. C.; Couto, J. L. \& de Azevedo, M. F. Cephalometric characteristics and dentofacial abnormalities of pycnodysostosis: report of four cases from Brazil. Oral Surg. Oral Med. Oral Pathol. Oral Radiol. Endod., 104(4):e83-90, 2007.

Francisco, J. V. \& Nicholoff, T. J. Jr. Pyknodysostosis: An unusual presentation in a denture wearer. Oral Surg. Oral Med. Oral Pathol., 72(6):693-5, 1991.

Gamboa Mejía, K.; González Trejo, J. \& Fragoso Ríos, R. Picnodisostosis. Rev. Odont. Mex., 9(2):92-6, 2005.

Goodman, R. M. \& Gorlin, R.J. Atlas of the face in genetic disorders. $8^{\text {th }}$ ed. Saint Louis, Mosby Co., 1977.

Hunt, N. P.; Cunningham, S. J.; Adnan, N. \& Harris, M. The dental, craniofacial and biochemical features of pyknodysostosis: a report of three new cases. J. Oral Maxillofac. Surg., 56(4):497-504, 1998.

Kamak, H.; Kamak, G. \& Yavuz, I. Clinical, radiographic, diagnostic and cephalometric features of pycnodysostosis in comparison with Turkish cephalometric norms: a case report. Eur. J. Dent., 6(4):454-9, 2012.

Kawahara, K.; Nishikiori, M.; Imai, K.; Kishi K. \& Fujiki, Y. Radiographic observations of pyknodysostosis. Report of a case. Oral Surg. Oral Med. Oral Pathol., 44(3):476-82, 1977.

Landa, S.; Esteban, S.; Montes, E.; Santamaria, J.; Vitoria, A. \& Santolaya, J. M. Maxillofacial alterations in a family with pycnodysostosis. Med. Oral, 5(3):169-76, 2000.

Marrero Riverón, L. O.; Rondón García, V.; Barbán Lores, D.; Morales Peralta, E. \& Quintana Rodríguez, F. J. Estudio en una familia de una paciente con picnodisostosis. Rev. Cubana Ortop. Traumatol., 18(1):34-40, 2004.

Muto, T.; Michiya, H.; Taira, H.; Murase, H. \& Kanazawa, M. Pycnodysostosis. Report of a case and review of the Japanese literature, with emphasis on oral and maxillofacial findings. Oral Surg. Oral Med. Oral Pathol., 72(4):449-55, 1991.

Nørholt, S. E.; Bjerregaard, J. \& Mosekilde, L. Maxillary distraction osteogenesis in a patient with pycnodysostosis: a case report. J. Oral Maxillofac. Surg., 62(8):1037-40, 2004.

Ramaiah, K. K.; George, G. B.; Padiyath, S.; Sethuraman, R. \& Cherian, B. Pyknodysostosis: report of a rare case with review of literature. Imaging Sci .Dent., 41(4):177-81, 2011.

Soliman, A. T.; Ramadan, M. A.; Sherif, A.; Aziz Bedair, E. S \& Rizk, M. M. Pycnodysostosis: clinical, radiologic, and endocrine evaluation and linear growth after growth hormone therapy. Metabolism, 50(8):905-11, 2011.

Wolpowitz, A. \& Matisonn, A. A comparative study of pycnodysostosis, cleidocranial dysostosis, osteopetrosis and acro-osteolysis. S. Afr. Med. J., 48(24):1011-8, 1974.

Correspondence to:

Nilton Alves

Departamento de Odontología Integral Adulto

Universidad de La Frontera

Temuco-CHILE

Received: 29-03-2013

Accepted: 05-06-2013

Email: Email: niltonnalves@yahoo.com.br 